\title{
Assessing Impact of Coordinated Comprehensive Regional Extension Publications: A Case Study of the Southern Nursery Integrated Pest Management Working Group
}

\author{
Matthew R. Chappell ${ }^{1,7}$, Sarah A. White ${ }^{2}$, Amy F. Fulcher ${ }^{3}$, \\ Anthony V. LeBude ${ }^{4}$, Gary W. Knox ${ }^{5}$, \\ and Jean-Jacques B. Dubois ${ }^{6}$
}

ADDITIONAL INDEX WORDS. survey, ornamental nursery production, ornamental field production, publication value, IPM

Summary. In 2014, the Southern Nursery Integrated Pest Management (SNIPM) Working Group published both print and electronic versions of IPM for Shrubs in Southeastern U.S. Nursery Production: Volume I. Five hundred print books (of 3000 copies) were distributed to commercial ornamental growers and extension educators in return for their participation in a follow-up survey. The survey was administered to determine the value of book contents, savings that growers realized from using the book, perceived value of the book had users been asked to pay for it, and demographic information. The survey response rate was $46.2 \%$, with respondents from 18 states. Of 243 respondents, $194(79.8 \%)$ had used the book. Entomology information was most used and most useful, followed by plant pathology, weed science, and cultural information. Collective savings attributed to book use totaled $\$ 408,832$ /year for the 194 nurseries that used the book. Applying the use rate $(79.8 \%)$ identified in this survey, this represents $\$ 5.62$ million in savings per year for the 3000 printed books, of which 2394 are estimated to have been used. Savings varied by the type and size of operation. Larger operations had greater savings per year. Container growers saved $\$ 44.15 /$ acre and field growers $\$ 28.37 /$ acre. The price that growers were willing to pay for the book also varied by operation type and size. Extension educators and growers were willing to pay an average of $\$ 41.20$, with an additional $\$ 0.063$ /acre for container growers and $\$ 0.126 /$ acre for field growers. Return on investment for the U.S. Department of Agriculture grant funding for the project was $\$ 187.60$ per dollar of funding. This survey demonstrates that collaborative efforts can produce high-value deliverables with significant regional and/or national impact.

$\mathrm{O}$ rnamental nursery production is an economically important sector of specialty crop agriculture in the United States, with 8226 growers producing nursery crops with a farm gate revenue of $\$ 4.3$ billion [U.S. Department of Agriculture (USDA), 2015]. The membership footprint of the SNIPM Working Group, formed to provide coordinated science-based information on integrated pest management (IPM) for nursery crop production in the southeastern United States, includes Florida, Georgia, Kentucky, North Carolina, South Carolina, Tennessee, and Virginia. In this region, there are 2483 growers producing nursery crops with an annual farm gate revenue of \$1.1 billion (USDA, 2015), or a quarter of all production in the United States. About 400 ornamental genera are grown by nurseries in these seven states (Yeager et al., 2007). Each crop (genus) has unique cultural and pest management requirements, mandating specific knowledge for successful production. Cultural and pest management protocols are specific to each crop within a nursery and thus present a significant management challenge. Historical lack of centralized knowledge on crop-specific practices is a contributing factor to crop losses, which can be significant (Fulcher et al., 2012). In Georgia, ornamental production losses in 2013 were estimated to be $9.4 \%$ of farm gate value or $\$ 46$ million (Little at al., 2014). Using USDA data to extrapolate losses across the SNIPM footprint at the rate reported in Georgia, regional reduction in profits would total \$106.1 million. These profit reductions include resources (e.g., monetary, chemical, and labor) spent on pest control, as well as lost sales due to either poor-quality stock or catastrophic crop failure.

The SNIPM Working Group was formed in 2009 (Fulcher et al., 2011) to reduce these losses and $\mathrm{co}^{-}$ ordinate the creation and production of extension resources. A primary goal of the group was to produce regional information to maximize impact, whereby extension specialists and researchers would not duplicate efforts in the development and production of deliverables such as the Pest Management Strategic Plan for Container and Field Produced Nursery Crops (LeBude and Fulcher, 2015). Resources produced by this working group have included a variety of traditional (print books) and electronic deliverables including electronic books (eBooks), mobile applications (apps), and downloadable files. The historic method of delivering topicfocused extension information is via printed text, which incurs greater development cost per project, but is still preferred by some extension clientele (Rodewald, 2001). Downloadable file formats [e.g., Adobe ${ }^{\circledR}$ PDF (Adobe, San Jose, CA)] gained popularity in the 1990s (Pfiffner, 2002), and in the last decade, eBook and app formats increased in popularity (Statista, 2017). The SNIPM Working Group has taken advantage of multiple publication formats (eBook and print) when releasing two previous books. The first book, IPM for Select Deciduous Trees in Southeastern U.S. Nursery Production (Fulcher and White, 2012), was released in June 2012. Subsequently, IPM for Shrubs in Southeastern U.S. Nursery Production: Volume I (White and Klingeman, 2014) was released in July 2014. The latter was a compilation of IPM information for five major shrubs in nursery crop production in the southeastern United States. This

\begin{tabular}{llll}
\hline $\begin{array}{l}\text { Units } \\
\text { To convert U.S. to SI, } \\
\text { multiply by }\end{array}$ & U.S. unit & SI unit & $\begin{array}{l}\text { To convert SI to U.S., } \\
\text { multiply by }\end{array}$ \\
\hline 0.4047 & acre(s) & ha & 2.4711
\end{tabular}


175-page book covered sustainable management practices for insects, mites, diseases, and weeds, as well as additional nursery production information. Included genera were selected based on USDA survey data (USDA, 2015) and grower feedback, focusing on genera with significant economic impact in the southeastern United States, including abelia (Abelia sp.), camellia (Camellia sp.), shrub rose (Rosa sp.), blueberry (Vaccinium sp.), and viburnum (Viburnum sp.). Each chapter also provided comprehensive information on the species, cultivars available, and cultural information deemed valuable to nursery production based on previous industry focus groups (LeBude and Fulcher, 2015). For each genus, the major pests, diseases, weeds, and abiotic disorders were presented, along with sustainable management methods and tables listing labeled pesticides and fungicides by mode of action and site.

Information on the impact of extension deliverables directed toward commercial horticulture producers is anecdotal and scarce, and the resources required to collect it are often prohibitive. For example, the SNIPM Working Group's first published book (IPM for Select Deciduous Trees in Southeastern U.S. Nursery Production) contained a voluntary survey included as a tear-out page,

\footnotetext{
This article results from the workshop "Advancing Technology Adoption and Achieving Extension Impact: A Working Group Success Story" held on 9 Aug. 2016, at the ASHS Annual Conference, Atlanta, GA and sponsored by the Nursery Crops Working Group (NUR).

Grant funding for this survey was provided by USDA-NIFA through a grant from the Southern Region IPM Center.

We also thank Paul Thomas and Nick Fuhrman for internal review of the publication.

${ }^{1}$ Department of Horticulture, University of Georgia, 324 Hoke Smith Building, Athens, GA 30602

${ }^{2}$ Department of Plant and Environmental Sciences, Clemson University, E-143 P\&AS, Clemson, SC 29634

${ }^{3}$ Department of Plant Sciences, University of Tennessee, 252 Ellington Plant Science Building, 2431 Joe Johnson Drive, Knoxville, TN 37996

${ }^{4}$ Department of Horticulture, North Carolina State University, 455 Research Drive, Mills River, NC 28759

${ }^{5}$ Department of Environmental Horticulture, University of Florida, 155 Research Road, Quincy, FL 32351

${ }^{6}$ Southern IPM Center, 1730 Varsity Drive, Suite 110, North Carolina State University Centennial Campus, Raleigh, NC 27606

${ }^{7}$ Corresponding author. E-mail: hortprod@uga.edu. doi: 10.21273/HORTTECH03753-17 real market, the estimate should in principle not be related to the type or size of nursery. However, users might use this response to convey more than their objective guess of how much the purchase price should be. Their response might be used to express their opinion of the usefulness of the book and might reflect how much money the nursery is willing to spend on books in general, which is likely commensurate to the size of the operation. The latter estimate of value was useful in estimating return on investment. Because budgets and revenues are proportional to acreage and the proportionality differs by type of nursery, estimates of return on investment are expected to be proportional to acreage and might differ among types of nurseries (container vs. field). They also provide a way to estimate the return to the nursery industry from the grant amount invested in creating and producing the book.
}

and respondents were asked to return the instrument by mail. Very few responses were recorded, and consequently, little data were obtained on user-defined impact of the publication. Respondents who did reply indicated an average savings of $\$ 3313$ based on improved pest management practices learned and implemented in their operations (A.F. Fulcher, unpublished data), but not enough responses were received to warrant publication of the results.

The goals of this survey were to gain a more comprehensive understanding of the demographics of those using the second book published by the SNIPM Working Group (IPM for Shrubs in Southeastern U.S. Nursery Production: Volume I) and to estimate the value of the book. As a result, this article should serve as a case study of the value of coordinated and comprehensive extension publications. Two aspects of that value were determined: first, the purchase value of the physical book as measured by willingness to pay and second, the investment worth of the information it contained, as measured by the monetary savings realized by using the book. The former was useful in estimating how much might be recouped should the resource not be distributed freely and how it compared with the amount of the grant that financed it. Because the purchase price of books does not normally vary for each buyer in the

\section{Materials and methods}

IPM FOR SHRUBS IN SOUTHEASTERN U.S. NURSERY PRODUCTION. Volume I was published in June 2014 (White and Klingeman, 2014). Publication included a print version, with 3000 units distributed primarily to commercial ornamental nursery container and field producers within the SNIPM footprint and to a lesser extent to commercial landscapers, as well as eBook and Apple iBook (Apple, Cupertino, CA) formats. Printed copies were also distributed outside of the SNIPM footprint, yet primarily within other southeastern states, to growers attending trade events within the region. Of the 3000 printed texts produced, 500 were used for the purpose of this survey. During the 2015 calendar year, books were given free of charge to growers and Cooperative Extension county and regional agents at four industry events including (number of recipients at each event in parentheses): the International Plant Propagator's Society-Southern Region Annual Conference (169), Gulf States Horticultural Expo (105), Georgia Green Industry Association WinterGreen Tradeshow (121), and Southern Nursery Association SEGreen (105). Recipients agreed at the time of receiving the book to provide contact information for a follow-up survey to be administered by phone or videoconference 12-18 months after receiving the book. This 12 - to 18-month period permitted recipients time to determine the value of the book independently. Recipients were also notified that they would receive the second book in this series [IPM for Shrubs in Southeastern U.S. Nursery Production: Volume II (Chappell et al., 2017)] free of charge for participating in the survey. It was assumed that receiving free printed materials would serve as a motivating factor for initial survey interest and later participation.

The survey instrument was developed as a coordinated effort between the University of Georgia and the Southern Region IPM Center (SIPMC). Ten questions were identified (Fig. 1) to gain an understanding of user demographics and how frequently the book was used, the value of information contained in the book, the perceived value of the book itself, and whether readers would like the SIPMC (or other entities) to 
1. Have you used the book? (If yes, continue at question 3. If not, answer question 2 and stop survey).

2. If not, why (select all that apply))?

Gave the book to someone else (Please provide name of the person who has the book.)

The information was not presented in a way that was easy for me to access or use.

We don't grow those crops.

Other. Please explain.

Provide contact information if you gave the book to another individual.

3. There are 5 sections in each chapter of the book or in the case of weeds it is a stand-alone chapter. I am going to ask you about each of the 5 .

\begin{tabular}{|l|l|l|l|}
\hline & $\begin{array}{l}\text { How often did you look at this section? } \\
\text { Please respond with a number from 1 } \\
\text { to 4; with 0=Never or almost never, 1= } \\
\text { A few times, 2= Sometimes, 3= Many } \\
\text { times, and 4= Very often or All the time }\end{array}$ & $\begin{array}{l}\text { How useful was this section } \\
(1=\text { not }-10=\text { extremely }) ?\end{array}$ & $\begin{array}{l}\text { If 'not } \\
\text { useful', } \\
\text { ask why. } \\
\text { why }\end{array}$ \\
\hline Weeds & & & \\
\hline Entomology & & & \\
\hline Plant pathology & & & \\
\hline Abiotic & & & \\
\hline Cultural practices & & & \\
\hline
\end{tabular}

4. How much has the information from this book saved or earned your business? For example, If this book saved you 3 pesticide applications, what would be the cost of applying that pesticide in labor, chemical cost and fuel/maintenance for application equipment, times 3 .
$\$ 0$
$\$ 1-500$
$\$ 501-1,000$
$\$ 1,001-5,000$
$\$ 5,001-10,000$
$>\$ 10,000$

5. Would additional information-based resources (provided by the authors of this book - e.g. books, websites, mobile apps, brochures, videos) like this one be of benefit to you business/career?

Yes No

6. If you were to buy this book, how much would you be willing to pay?

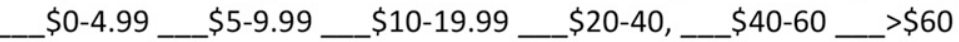

7. Which of the following best describes your business?

Container nursery

Field nursery

Landscaping

Arborist

Garden center

Education

Other, please fill in:

8. In what state is your operation located? (can be indicated by person who calls the respondent)

9. What is the acreage of your operation? acres

10. Do you primarily use online or print materials as an information source when making production-related decisions? Online Print

Fig. 1. The survey instrument used in this study included 10 questions developed to collect basic demographic information of respondents and to understand usefulness of information and economic impact of information contained within IPM for Shrubs in Southeastern U.S. Nursery Production: Volume I (White and Klingeman, 2014).

produce/fund similar information sources in the future. After initiating the survey in May 2016, it became apparent that an overwhelming number of respondents were refusing to answer the question, "What is your operation's gross income last year (before taxes)?" As a result, this question was replaced with question 10 in 
Fig. 1; "Do you primarily use online or print materials as an information source when making productionrelated decisions?" At this point in the survey, 19 respondents had been surveyed and all 19 were contacted to record a response to the revised survey question 10.

The survey was administered between May 2016 and Feb. 2017. Respondents were contacted using the information provided to the SNIPM Working Group when they received the first book, IPM for Shrubs in Southeastern U.S. Nursery Production: Volume I (White and Klingeman, 2014). If the respondent had changed employers, contact information was requested via e-mail or from the previous employer and follow-up contact attempted. When respondents indicated that they had given the book to another individual, an effort was made to contact the eventual user of the book. In total, 500 books were distributed, and an attempt was made to contact $\mathbf{5 2 6}$ individuals to administer the survey ( 26 persons were given the book by the initial survey contact). The average survey contact (conversation) was $22 \mathrm{~min}$, and on average, 2.6 contacts were made to successfully administer the survey. After five failed attempts to contact individuals, they were classified as nonrespondents. To facilitate delivery of a survey, when a survey was administered, a text message or e-mail containing the questions was sent concurrently. This allowed respondents to view the questions and response scales while answering the interviewer, and respondents overwhelmingly voiced appreciation for this arrangement. Among potential sources of response bias, if any are present in this survey, the most likely would be a form of social desirability bias (Lavrakas, 2008) whereby some respondents might adjust their true estimates of use and value upward to please the interviewer. We countered this by 1 ) warning respondents against it, 2) informing them clearly of the anonymity of the survey, 3 ) directing respondents to use objective measurements of use and value, and 4) maintaining a neutral, impersonal, and consistent behavior throughout each interview.

The survey had 243 respondents, or a $46.2 \%$ response rate. Respondents were based in 18 states, including (number of respondents in parentheses) Georgia (30), North Carolina (26), Florida (18), Alabama (17), Virginia (16), South Carolina (15), Tennessee (13), Maryland (8), Mississippi (6), Kentucky (5), Pennsylvania (5), Texas (4), Louisiana (3), Delaware (2), Ohio (2), West Virginia (2), Arkansas (1), and Massachusetts (1). All respondents fell into three categories: container nursery [157 (80.9\% of respondents)], field nursery [17 ( $8.7 \%$ of respondents)], and education [20 (10.3\% of respondents)].

Savings and willingness to pay data (Questions 4 and 6) were collected as interval data (Fig. 1). Respondents were asked how much the information in the book had saved or earned their business, in one of six unequal intervals: $\$ 0, \$ 1$ to $\$ 500$, $\$ 501$ to $\$ 1000, \$ 1001$ to $\$ 5000$, $\$ 5001$ to $\$ 10,000$, with the exact value requested from the six respondents who estimated the savings to be greater than $\$ 10,000$. Likewise, intervals for willingness to pay for the book were $\$ 0.00$ to $\$ 4.99, \$ 5.00$ to $\$ 9.99, \$ 10.00$ to $\$ 19.99, \$ 20.00$ to $\$ 40.00, \quad \$ 40.00$ to $\$ 60.00$, and greater than $\$ 60.00$. Data such as these, where an underlying continuous variable is measured within known intervals, without information about where exactly within the interval the precise value lays, are said to be interval censored (Sun, 2006). In the case of the upper interval of willingness to pay, where the highest interval is unbounded, that highest value $(\$ 60.00)$ is right censored.

Hasselblad et al. (1980) and Hsiao (1983) demonstrated that analyzing interval-censored data using ordinary least square regression (for example, to obtain an estimate of savings per acre, or test differences in willingness to pay between groups of users) yields estimates that are inconsistent and inaccurate, and biased tests of hypothesis. We therefore used a modified Tobit regression model as described by Long (1997) and Stewart (1983) and implemented in PROC LIFEREG of the SAS (version 9.3 for Windows; SAS Institute, Cary, NC). The effect of acreage was nested within nursery type, as the productivity per acre of container and field nurseries was known to be very different. When adding the total collective savings for all growers in the sample, we used the customary method of summing the midpoints of the intervals, except for those respondents who selected the exact value of $\$ 0$, or an exact value greater than $\$ 10,000$, where we used the exact value given by the respondent.

\section{Results and discussion}

Questions 1 and 2. Of the $\mathbf{5 2 6}$ individuals identified among the recipients of the book, $243(46.2 \%)$ participated in the survey. Of these $243,194(79.8 \%)$ had used the book, whereas the remaining $49(20.2 \%)$ had not. Using a follow-up question, of those who had not used the book, $26(10.7 \%)$ had given the book to another individual, most frequently an individual within the same operation who was responsible for pest management decisions. Of those who did not give the book to another individual, $15(6.2 \%)$ indicated that they did not grow the five genera included in the book. Three individuals $(1.2 \%)$ indicated the information was not presented in a way that was easy to access, and another three individuals lost or damaged the book.

Question 3. The respondents were then asked about each of the sections within the book and how frequently they looked at each section, followed by determination of the utility of the information within a section (Fig. 2). When assessing both frequency of use and utility of information, the entomology section was most highly rated. Entomology information was accessed more frequently [median = 3 (i.e., many times)] and was rated as most useful $($ median $=8)$. The plant pathology section was the next most valued section based on frequency of access ( median $=3$ ) and utility of information (median $=7$ ). Information within the weeds section was accessed less frequently $[$ median $=2$ (i.e., sometimes)], but the information was considered very useful (median $=7$ ). Cultural information was not accessed frequently $[$ median $=1$ (i.e., a few times)], but the information was valued when accessed (median $=6$ ). Abiotic information was neither accessed [median $=0$ (i.e., never or almost never)] nor considered useful $($ median $=1)$.

A limitation of the survey questions was that we did not ask respondents why they found the information useful; we only asked why they did not find the information useful. The 


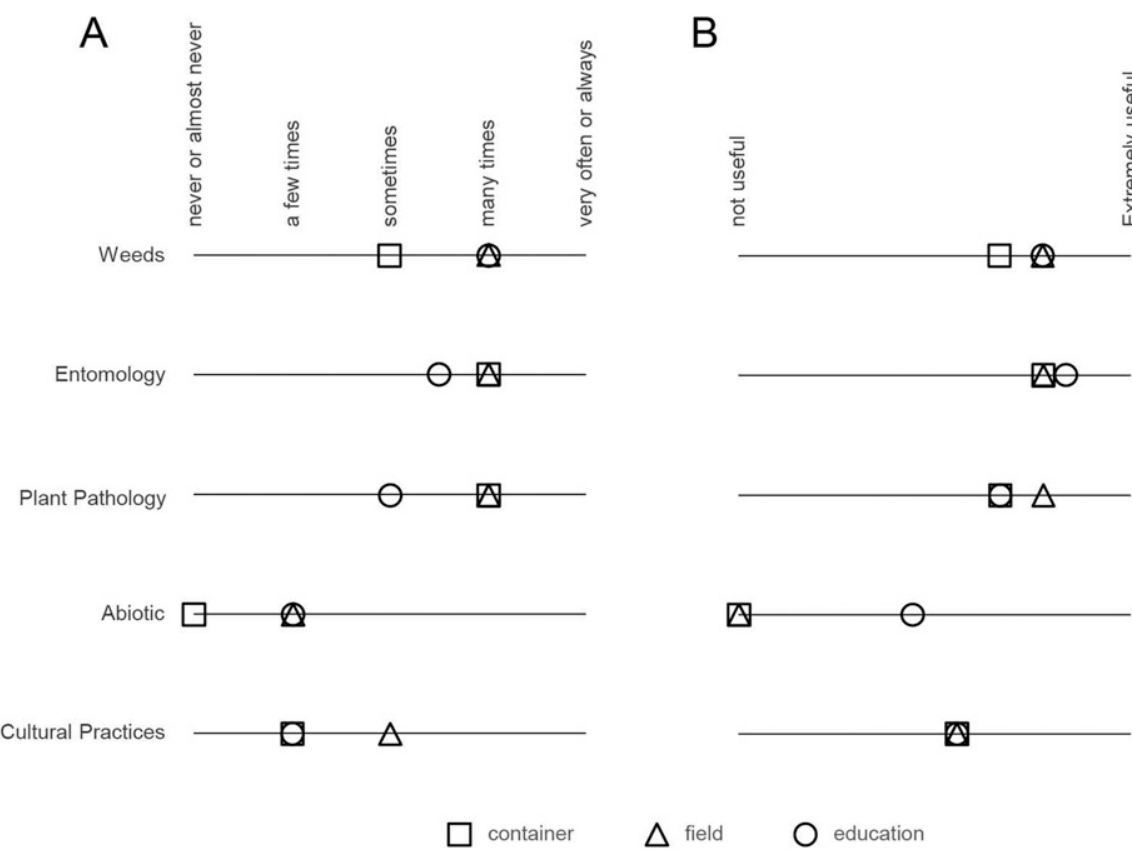

Fig. 2. Median frequency of use (A) and utility (B) of sections within each chapter of IPM for Shrubs in Southeastern U.S. Nursery Production: Volume I (White and Klingeman, 2014) as rated by container nursery growers, field nursery growers, and extension educators.

perceived value of entomology, plant pathology, and weed sections, based on nondocumented conversations with respondents, was likely because of pest-specific details related to pest biology and chemical treatment options available. Before this publication, to our knowledge, collated information related to pest biology and chemical treatment options were not readily available from any other information source for the documented ornamental genera. As with previous crop-specific IPM publications, simply providing novel crop-specific IPM information that is targeted to producers resulted in respondents identifying the information as useful (McNamara et al., 1991).

When investigating the reasons why cultural information were used infrequently or not found useful, the overarching consensus from respondents was that although the information was important, they were more concerned with pest-specific information. A secondary reason was that information provided on cultivars required updating, as 3 years after release, the cultivar tables were outdated because ofthe pace of new cultivar introduction into the marketplace. This presents a significant challenge to extension authors and funding agencies when constructing or funding coordinated deliverables in that resources must be allocated to maintain relevance and accuracy of the information provided not only at the time of publication but also into the future (Peet, 1998).

Abiotic information was overwhelmingly not used or useful. The information was deemed good, but not needed. Oftentimes, this was because the information was acquired elsewhere or was resident knowledge to the organization. A smaller number of respondents indicated that the section was read once, but did not require revisiting because of the simplicity of concepts provided.

Question 4. Respondents were asked if information in the book saved either them money or inputs and to assign a monetary value to those savings on an annual basis. Education users $(n=20)$ did not report on acreage or savings.

TOTAL SAVINGS AND RETURN ON INVESTMENT. Total collective savings for the 157 container nurseries sampled was $\$ 346,574$ per year. Total collective savings for the 17 field nurseries computed in the same way was $\$ 62,259$, or $\$ 408,832$ per year for the 174 nurseries. Applying the $79.8 \%$ use rate to the 3000 books, savings to nursery growers from the book is about $\$ 5.62$ million per year. The amount of the SIPMC grant that financed the book was $\$ 29,983$, for a return on investment of $\$ 188$ per dollar of grant funding.

EXPECTED SAVINGS PER ACRE. Because the amount saved was expected to be proportional to acreage, those totals were sensitive to the distribution of acreage among nurseries. Therefore, we computed savings per acre for the 174 nurseries. The distribution of amount saved per acre for the sample of nurseries is presented in Fig. 3. The Tobit regression used to account for the interval censoring in the savings data showed that as expected the amount saved increased significantly with acreage $(P<0.001)$ and was significantly different for container and field nurseries $(P<$ $0.001)$. The expected amount saved by container nurseries per acre and per year was $\$ 44.15$ [ $\$ 38.95$ to $\$ 49.34$ (95\% confidence interval)], and $\$ 28.37$ [ $\$ 18.41$ to $\$ 38.33$ (95\% confidence interval)] per acre and per year for field nurseries. These estimates assume that the relationship between acreage and savings was directly proportional (straight line). Should it not be directly proportional, for example, if larger nurseries can realize greater savings per acre from using the book than smaller ones, these estimates of savings per acre would then be somewhat too large for small nurseries and too small for large ones. The data available were not sufficient to estimate curved relationships between acreage and savings.

The range of acreage within each saving interval was notably wide. For example, in the $\$ 501$ and $\$ 1000$ savings interval, $90 \%$ of container operations were between 18 and 83 acres. This variability was partially due to the use of intervals to register savings, but unrecorded factors may have also influenced the rate of savings per acre from using the practices in the book. Hypothetically, these unrecorded factors might include the mix of shrubs grown, market type for the shrubs sold, labor management, and very likely how many of the management practices included in the book were already being used by a respondent before receiving the book, similar to other IPM value studies (McNamara et al., 1991). The 

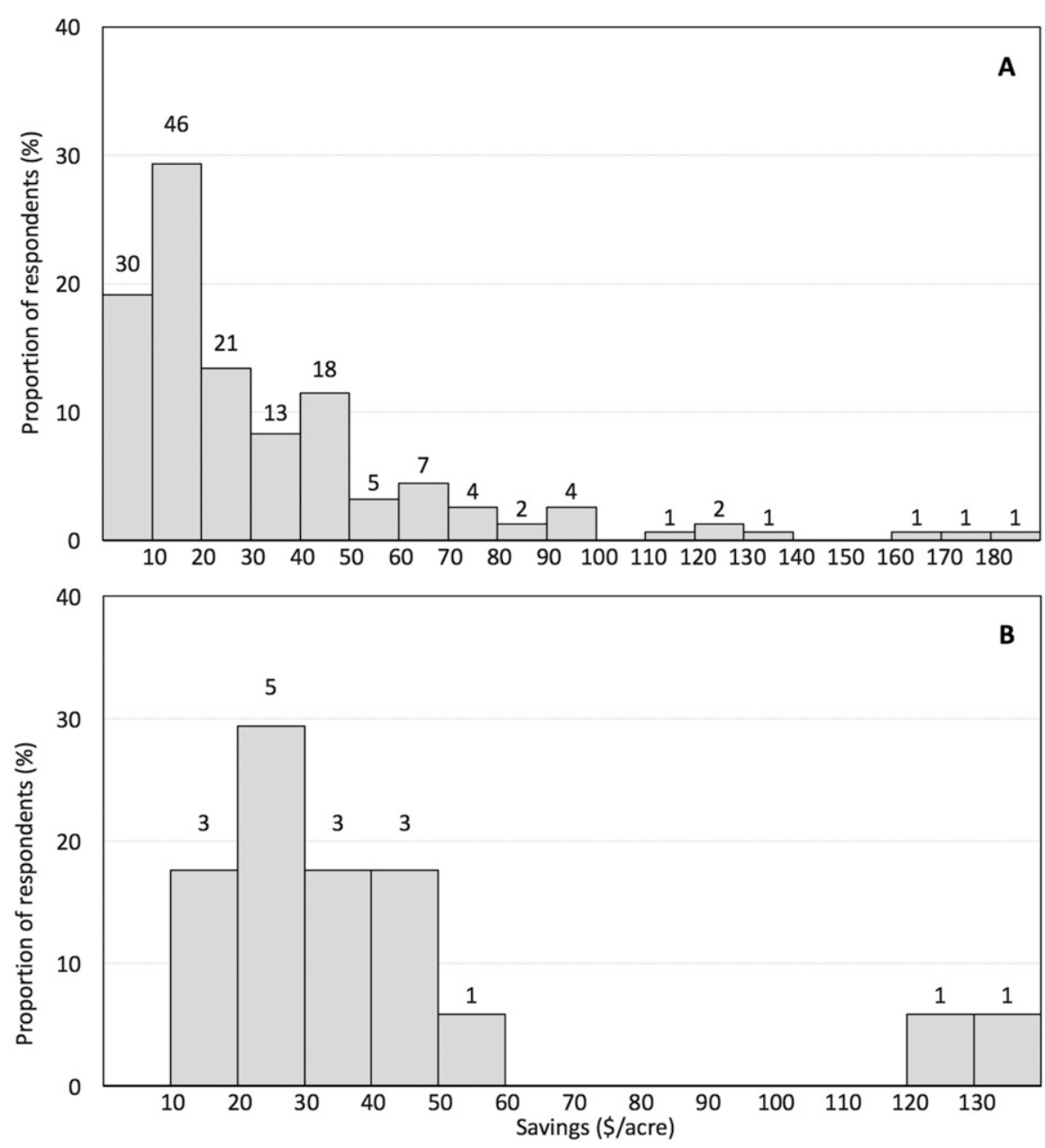

Fig. 3. Sample distribution of the amount saved per acre by 154 container (A) and 17 field (B) nursery producers, as computed from each nursery's acreage and savings attributed by each grower to using the information in IPM for Shrubs in Southeastern U.S. Nursery Production: Volume I (White and Klingeman, 2014). Numbers on bars are the number of respondents; $\$ 1.00 / \mathrm{acre}=\$ 2.4711 / \mathrm{ha}$.

$\$ 44.15$ and $\$ 28.37$ estimates are therefore valid overall, and within the range of acreage in the sample. Savings per acre may be higher or lower than these depending, for example, on those unrecorded factors, but would converge to those values for all container and field operations, respectively.

Question 5. Respondents were asked if additional information resources like this one would be of benefit to their business and career. Of grower respondents $(n=174)$, 97\% indicated there would be benefit from additional resources. Of extension educator respondents $(n=49)$, $100 \%$ indicated there would be benefit from additional resources.

Question 6. Respondents were asked to tell us how much they would have been willing to pay if they had purchased the printed book. Because of the interval censoring and rightcensoring of the data (Fig. 1), modified Tobit regression was used to analyze the willingness-to-pay data as well, with acreage nested in user type. The willingness to pay was different between user groups $(P=0.003)$, but unexpectedly, acreage influenced willingness to pay $(P=0.040)$. In other words, even though the stated purchase value of the book was expected to be the same for all users, container growers and field growers were willing to add a premium to the purchase price of the book depending on the acreage of their operation, which has been observed in the implementation of larger farm-scale environmental practices (Vanslembrouck et al., 2002) but not documented to our knowledge in the purchase of IPM resources. This likely means that as a measurement of the potential purchase price of the book itself, willingness to pay was somewhat contaminated by judgments of the value of using the book. Education readers and growers would be willing to pay $\$ 41.20$, with an additional $\$ 0.063$ per acre for container growers and $\$ 0.126$ per acre for field growers. When determining the number of books that would have to be sold to match the grant amount, we used the $\$ 41.20$ value as an overall estimate. Given the \$29,983 grant amount, 727 books would have to be sold. The purchase value of the 3000 books, on the other hand, was $\$ 123,600$, or four times the grant amount, demonstrating that by funding the book with public funds and distributing it freely, the funding agency was able to disseminate the information at a considerable discount.

Question 10. Respondents were asked if they primarily use electronic or print resources to make cultural or pest management decisions. Of the 174 producers surveyed, 36\% preferred printed materials and 64\% preferred electronic materials. The primary reason given for preference of electronic materials was the quickness of finding desired information via search function; findability was noted as a driver of eBook use by van der Velde and Ernst (2009). Yet, van der Velde and Ernst (2009) also reported that print book usage was not declining, but in some cases eBook use drove print book sales. Predictably, $73 \%$ of educators preferred electronic materials, again related to the search ability within electronic documents.

\section{Conclusions}

Person-to-person survey methodology resulted in a high (48.6\%) response rate. In addition, respondents were distributed among container and field operations, with additional respondents recorded from educational backgrounds (e.g., Cooperative Extension county or regional agents). When respondents indicated that they did not use the book, $50 \%$ gave the book to another individual in their organization with primary pest management responsibility. Of those who used the book, the entomology, plant pathology, and weed science sections were found to be most useful. The one limitation of large, comprehensive 
regional publications appears to be that cultural information (e.g., cultivar tables) as well as pesticide tables should be updated on a regular basis to maintain relevancy and accuracy. In addition, based on the size of the business where the respondent is employed, it was apparent that economy of scale is an important determining factor in how much monetary impact the information had on the specific business and the willingness to pay for a similar book. Growers and educators alike responded that they would like to see more resources such as this book. A shortcoming of this survey was that questions were only asked as to why something was not valued, rather than why information was valued or useful.

This survey only requested feedback on the printed version of the book, not on the electronic versions of the book, which were concurrently available. This was because no contact information was available for individuals who downloaded electronic copies. This lack of contact information for electronic users underlines the inherent difficulty of effectively assessing the comprehensive impact of extension resources made available in traditional and electronic formats. In this case, unique electronic downloads of the book (eBook and .pdf versions) totaled $481(16 \%)$ of all readers, with downloads from 31 countries in addition to the United States. Nonetheless, these data point to a significant impact achieved through a coordinated regional extension effort to provide growers with (economically important) crop-specific IPM information.

\section{Literature cited}

Chappell, M., G.W. Knox, and G. Fernandez (eds.). 2017. IPM for shrubs in southeastern U.S. nursery production: Volume II. Southern Nursery IPM Working Group, Clemson, SC.

Fulcher, A., C. Adkins, K. Braman, M.R. Chappell, J-H. Chong, W. Dunwell, S. Frank, F. Hale, K. Ivors, W. Klingeman, III., A.V. LeBude, J. Neal, S. White, J.
Williams-Woodward, and A. Windham. 2011. Multiplier effect of collaborative nursery crops programming on outputs and outcomes. HortScience 46:S377S378. (Abstr.).

Fulcher, A., W.E. Klingeman, J-H. Chong, A. LeBude, G.R. Armel, M. Chappell, A. Frank, F. Hale, J. Neal, S. White, J. Williams-Woodward, K. Ivors, C. Adkins, A. Senesac, and A. Windham. 2012. Stakeholder vision of future direction and strategies for southeastern U.S. nursery pest research and extension programming. J. Integrated Pest Mgt. 3:2):Dl-D8. 13 June 2017. <https:// academic.oup.com/jipm/articlelookup/doi/10.1603/IPM11030>.

Fulcher, A.F. and S.A. White (eds.). 2012. IPM for select deciduous trees in southeastern U.S. nursery production. Southern Nursery IPM Working Group, Clemson, SC.

Hasselblad, V., A.G. Stead, and W. Galke. 1980. Analysis of coarsely grouped data from the lognormal distribution. J. Amer. Stat. Assn. 75:771-778.

Hsiao, C. 1983. Regression analysis with a categorized explanatory variable, p. 93129. In: S. Karlin, T. Amemiya, and L. Goodman (eds.). Studies in econometrics, time series and multivariate analysis. Academic Press, New York, NY.

Lavrakas, P.J. 2008. Encyclopedia of survey research methods. SAGE Publ., Thousand Oaks, CA.

LeBude, A.V. and A. Fulcher (eds.). 2015. Pest management strategic plan for container and field-produced nursery crops: Revision 2015. 13 June 2017 . <http:www.go.ncsu.edu/ NurseryCropsIPM2015>.

Little, E., P. Brannen, J. Brock, B. Dutta, G. Jagdale, A. Jogi, B. Kemerait, A. Martinez-Espinoza, and J. WilliamsWoodward. 2014. Georgia plant disease loss estimates, 2014. Univ. Georgia Coop. Ext. Serv. Bul. AP 102-7.

Long, J.S. 1997. Regression models for categorical and limited dependent variables. Sage Publ., Thousand Oaks, CA.

McNamara, K.T., M.E. Wetzstein, and G.K. Douce. 1991. Factors affecting peanut producer adoption of integrated pest management. Rev. Agr. Econ. 13:129139.

Peet, M.M. 1998. Developing, converting, and maintaining information-rich resources on the world wide web. HortTechnology 8:307-312.

Pfiffner, P. 2002. Inside the publishing revolution: The Adobe story. Adobe Press, San Francisco, CA.

Rodewald, A. 2001. Delivery systems - Is the "latest" technology the greatest?. J. Ext.39(4)4TOT213 June 2017. <https:// www.joe.org/joe/200 laugust/tt2.php>.

Statista. 2017. Number of e-books sold in the United States from 2010 to 2015 (in million units). 13 June 2017. <https:// www.statista.com/statistics /426799/ebook-unit-sales-usa/>.

Stewart, M.B. 1983. On least squares estimation when the dependent variable is grouped. Rev. Econ. Stud. 50:737-753.

Sun, J. 2006. The statistical analysis of interval-censored failure time data. Springer-Verlag, New York, NY.

U.S. Department of Agriculture. 2015. 2013 census of agriculture. Census of horticultural specialties (2014), Vol. 3. Special studies. Part 3. AC-12-SS-3. 13 June 2017. <https://www.agcensus. usda.gov/Publications/2012/Online_ Resources/Census_of_Horticulture_ Specialties/HORTIC.pdf $>$.

van der Velde, W. and O. Ernst. 2009. The future of eBooks? Will print disappear? An end-user perspective. Libr. Hi Tech 27:570-583.

Vanslembrouck, I., G. van Huylenbroeck, and W. Verbeke. 2002. Determinants of the willingness of Belgian farmers to participate in agri-environmental measures. J. Agr. Econ. 53:489-511.

White, S.A. and W.E. Klingeman (eds.). 2014. IPM for shrubs in southeastern U.S. nursery production: Volume I. Southern Nursery IPM Working Group, Clemson, SC.

Yeager, T.H., C.H. Gilliam, T.E. Bilderback, D.C. Fare, A.X. Niemiera, and K.M. Tilt. 2007. Best management practices guide for producing container-grown plants. 13 June 2017. <http://contents.sna.org/bmpv30. html $>$. 